\title{
Microbiological Indicators of Soil Quality Under Native Forests are Influenced by Topographic Factors
}

\author{
ANITA F.S. TEIXEIRA ${ }^{1}$, JACQUELINE S. SILVA ${ }^{1}$, LAÍZE A.F. VILELA ${ }^{1,2}$, PATRÍCIA F. COSTA ${ }^{1,3}$, \\ ELAINE M. DA COSTA ${ }^{1,4}$, AMANDA A. GUIMARÃES ${ }^{1}$, JESSÉ $\mathbf{V}$. DOS SANTOS ${ }^{1}$, SÉRGIO \\ H.G. SILVA ${ }^{1}$, MARCO AURÉLIO C. CARNEIRO ${ }^{1}$ and FATIMA M.S. MOREIRA ${ }^{1}$
}

\author{
${ }^{1}$ Departamento de Ciência do Solo, Universidade Federal de Lavras/UFLA, Caixa Postal 3037, 37200-000 Lavras, MG, Brazil \\ ${ }^{2}$ Centro de Ciências da Natureza/CCN, Universidade Federal de São Carlos/UFSCar, Campus Lagoa do Sino, \\ Rua Serafim Libaneo, 4, Centro, Caixa Postal 64, 18245-970 Campina do Monte Alegre, SP, Brazil \\ ${ }^{3}$ Instituto Federal de Minas Gerais/IFMG, Campus Avançado de Ponte Nova, Praça \\ José Emiliano Dias, 87, Centro, 35430-034 Ponte Nova, MG, Brazil \\ ${ }^{4}$ Universidade Federal do Piauí, Campus Professora Cinobelina Elvas, Av. Manoel \\ Gracindo, Km 1, Planalto Horizonte, 64900-000 Bom Jesus, PI, Brazil
}

How to cite: TEIXEIRA AFS, SILVA JS, VILELA LAF, COSTA PF, COSTA EM, GUIMARÃES AA, SANTOS JV, SILVA SHG, CARNEIRO MAC AND MOREIRA FMS. 2019. Microbiological Indicators of Soil Quality Under Native Forests are Influenced by Topographic Factors. An Acad Bras Cienc 91: e20180696. DOI 10.1590/00013765201920189696.

\begin{abstract}
Several microbiological indicators of soil quality present high sensitivity, but little is known about the influence of topographic factors on them. This work aimed to evaluate variability of biological indicators of soil quality across a hillslope under native forest and the influence of topographic factors on them. Four positions on a hillslope were evaluated. Activity of the enzymes $\beta$-glucosidase, acid phosphatase, urease and fluorescein diacetate (FDA) hydrolysis were determined, as well as basal and substrate-induced respiration, and density of microorganisms: total bacteria, total fungi, actinobacteria, phosphate solubilizers, ammonifiers, native rhizobia, free-living $\mathrm{N}_{2}$-fixing bacteria, spores of arbuscular mycorrhizal fungi and percentage of root colonization by arbuscular mycorrhizal fungi. Activity and density of microorganisms were correlated with topographic factors. The relation of these factors to the variations of the evaluated indicators was determined using the random forest algorithm. Microbiological indicators varied according to the hillslope positions. The indicators urease, basal respiration, spore density, mycorrhizal colonization, total bacteria and fungi, phosphate solubilizers, and free-living $\mathrm{N}_{2}$ fixing bacteria detected in JNFB and FAM culture medium did not vary with terrain attributes and were therefore more indicated in cases of topographic variations. This and future studies can help to select the best microbiological indicators for different conditions.
\end{abstract}

Key words: Biological indicators, digital elevation model, enzymes, microbial activity, random forest.

\section{INTRODUCTION}

Soil is a heterogeneous and dynamic system and

Correspondence to: Fatima Maria de Souza Moreira

E-mail: fmoreira@ufla.br

ORCid: https://orcid.org/0000-0003-0159-5811 results from the combination of parent material, relief, climate, time and organisms (Jenny 1941, Resende et al. 2014). Soil complexity provides different habitats, which generate conditions for a great diversity of metabolically distinct organisms 
to perform their functions side by side to maintain soil quality (Moreira et al. 2006). Soil quality, the ability of a soil to function within the limits of a natural or managed ecosystem (Doran and Parkin, 1994) can be determined by physical, chemical, and biological indicators. These latter are evaluated by processes carried out by the microbial community, which guarantee the maintenance and productivity of ecosystems, such as the carbon cycle and plant nutrients in the soil (Swift et al. 2010). However, the microbial community is very sensitive to the effects of biotic and abiotic variables (Esch et al. 2017, Faucon et al. 2017) and topographic factors related to relief may influence the intensity of these variations.

The diversity of organisms guarantees the functional redundancy, which leads to the resilience of the environments (Moreira et al. 2013), since soil microorganisms are directly related to essential processes and sustainability of ecosystems (Moreira and Campos 2013). However, only a small part of these microorganisms are cultivable, which makes it impractical to isolate them to evaluate their activity in soil and to allow inferences about the system. To meet this need, not only organisms that contribute to processes that support the provision of ecosystem services are more commonly evaluated, but also indirect assessments of activity of microorganisms that contribute to soil quality, such as enzyme activity evaluations, can be made (Štursová et al. 2016, Santos et al. 2016, Moreira et al. 2013).

Among the influences of relief in soil habitats, hillslope position may provide different moisture conditions over time (Kim 2016). This may lead to the generation of habitats that favor different groups of microorganisms, even in soils under a unique type of vegetation, the same can be observed in areas with varying temperatures (Silva et al. 2018).

In recent years, the influence of topographic factors on the variability of soil classes and physical and chemical properties has been intensively studied, which was facilitated by the emergence of digital soil mapping tools that use terrain maps to aid in the establishment of such relationships (Ochoa et al. 2016, Silva et al. 2016a, Menezes et al. 2016, Moore et al. 1993, McBratney et al. 2003, Mckay et al. 2010). Such terrain maps are commonly derived from a Digital Elevation Model (DEM), which consists of a continuous and pixel by pixel representation of the altitude across an area of interest. From a DEM, various terrain maps, such as slope gradient, topographic wetness index, profile and planform curvatures, and others, can be created and correlated with soil properties variability. However, the influence of these topographical factors on soil biological attributes is still rarely addressed worldwide.

Studies on the influence of topographic factors on soil quality indicators may contribute to understanding these latter variations and consequently their role in the functioning of ecosystems. Also, by comprehending these relationships, inferences can be made regarding soil microbiological attributes through terrain analyses. The hypothesis of this study is that the microbiological attributes indicators of soil quality vary along with topographic factors found in the same area, thus, by analyzing topographic factors, which are more easily obtained, it is possible to infer about microbiological attributes indicators of soil quality. Thus, the present work aimed at establishing relationships between topographic factors and microbiological attributes indicators of soil quality across a hillslope under native forest in Brazil.

\section{MATERIALS AND METHODS}

\section{CHARACTERIZATION OF THE AREA}

The study area is located at Bocaina Mountain Range, in the municipality of Lavras - Minas Gerais state, Brazil, at latitude $21^{\circ} 19^{\prime} 49.93$ 'S and longitude $44^{\circ} 58^{\prime} 12.60^{\prime}$ 'W (Figure 1). The 
climate of the region is $\mathrm{Cwb}$, according to the Köppen classification, with hot and rainy summers and mild and dry winters (Alvares et al. 2013). The average annual rainfall is $1,373 \mathrm{~mm}$ and the average temperature varies between $19.7^{\circ} \mathrm{C}$ in winter and $22.7^{\circ} \mathrm{C}$ in summer (Sá Júnior and Carvalho 2012). The vegetation is classified as semi-deciduous high montane forest of the Atlantic Forest domain (Oliveira-Filho and Fontes 2000) with great richness of plants of the families Myrtaceae, Fabaceae, Melastomataceae, Lauraceae and Asteraceae (Dalanesi et al. 2004).

Along a hillslope, contemplating the upper, middle, and lower backslopes and footslope, four positions were evaluated under native semideciduous seasonal forest (Figure 1). At those hillslope positions, soil samples were collected at a depth of 0-20 cm, in four replicates at each place collected five and ten meters to the east and west from the central point, as illustrated in Figure 1. At each hillslope position, soils were classified according to the Brazilian Soil Classification System (Santos et al. 2018) and US Soil Taxonomy (Soil Survey Staff 2014).

Chemical characterization of the soils was made for each hillslope position through composite samples. The following chemical attributes were obtained: $\mathrm{pH}$ in water; exchangeable $\mathrm{Ca}^{2+}, \mathrm{Mg}^{2+}$ and $\mathrm{Al}^{3+}$ contents extracted with $1 \mathrm{~mol} \mathrm{~L}^{-1} \mathrm{KCl}$ (McLean et al. 1958); exchangeable contents of P and K (Mehlich 1953); H + Al (Shoemaker et al. 1961); organic carbon (Walkley and Black 1934) (orgC); and remaining phosphorus (P-rem) (Alvarez V and Fonseca 1990), which is an index that measures the retention capacity of $\mathrm{P}$ by the soil added to $10 \mathrm{mmol} \mathrm{L}^{-1} \mathrm{CaCl}_{2}$ solution with P $60 \mathrm{mg} \mathrm{L}^{-1}$. The more weathered and acidic the soil, the higher the phosphate adsorption and the lower the P-rem contents. Soil physical attributes were obtained through particle size analysis by the Bouyoucos method modified by Casagrande and Prószyñski (Ryzak et al. 2009), soil bulk density
(BD) was obtained, and amounts of micro and macropores (Mi and Ma) (Donagema et al. 2011) were determined from the collection of undisturbed samples at the central point at each hillslope position.

EVALUATION OF MICROBIOLOGICAL ATTRIBUTES INDICATORS OF SOIL QUALITY

The soil biological attributes were determined from each of the four simple samples collected at each hillslope position. Serial dilutions (Wollum 1982) were performed with $10 \mathrm{~g}$ of soil per sample in $90 \mathrm{~mL}$ of sterile saline solution $(0.85 \%)$, shaken (125 RPM) for 30 minutes, and $0.1 \mathrm{~mL}$ aliquots inoculated in media for the counting of groups of cultivable microorganisms by colony forming units (CFU) in triplicate. The culture media used were Thornton's (Thornton 1922) for total bacteria, SNC agar for actinobacteria (Wollum 1982), Martin culture medium for total fungi (Martin 1950), liquid media for ammonifiers (Soriano and Walker 1968) and glucose soil extract (GSE) for phosphate solubilizers (Sylvester-Bradley et al. 1982). The density of associative diazotrophic bacteria by most probable number (MPN) was determined using the semi-solid media, NFB (selective for Azospirillum spp.), FAM (selective for Azospirillum amazonense) and JNFB (selective for Hebaspirillum spp.) (Döbereiner et al. 1995, Magalhães et al. 1983).

Legume-nodulating bacteria were captured in a greenhouse experiment using as bait cowpea plants [Vigna unguiculata (L.) Walp], cultivated for 50 days in $(1: 1, \mathrm{v}: \mathrm{v})$ sterile mixture of sand and vermiculite inoculated with $1 \mathrm{~g}$ of soil mixed to $10 \%$ concentration in sterile sand. The plants were watered with Hoagland solution at low nitrogen concentration (5.25 $\mathrm{mg} \mathrm{L}^{-1}$ de N), except for the control with higher doses of this nutrient $(52.5 \mathrm{mg}$ $\left.\mathrm{L}^{-1}\right)$. Density was determined by MPN and number of nodules (NN). Nodule dry mass (NDM) and shoot dry matter (SDM) were observed. 

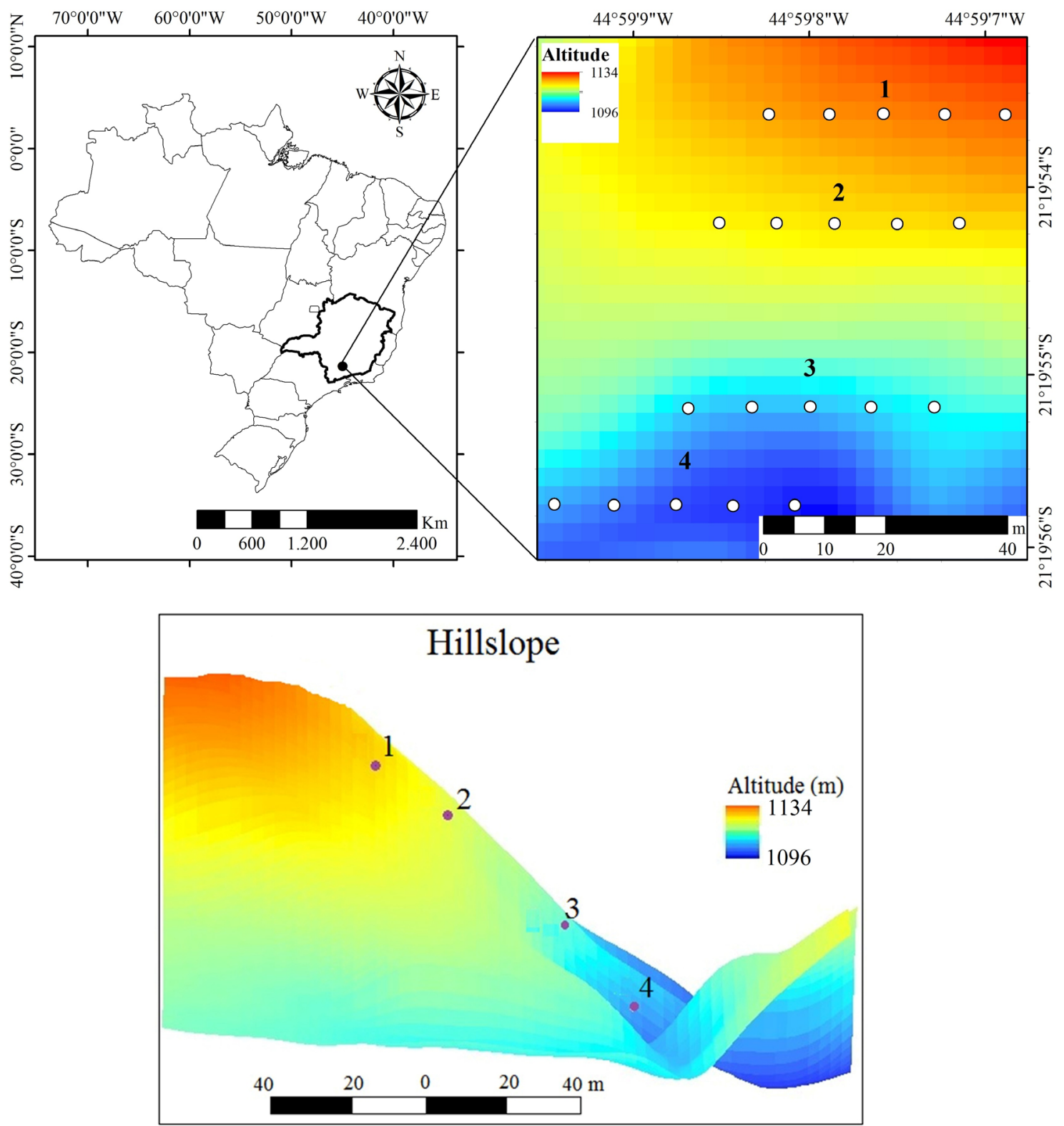

Figure 1 - Sampling scheme and altitudes obtained by Geographic Information System of the studied hillslope at Bocaina Mountain Range, in Lavras - Minas Gerais, Brazil.

Mycorrhizal colonization by arbuscular mycorrhizal fungi (AMF) of roots obtained from the soil was done by clarification and staining with trypan blue (Koske and Gemma 1989) and the quantification was given by the checkerboard method in which AMF spores were extracted from $50 \mathrm{~mL}$ of soil by the wet sieving technique (Gerdemann and Nicolson 1963) followed by water and sucrose centrifugation (Jenkins 1964).
The activity of the urease enzyme was based on the determination of the ammonia released after the incubation of soil with a urea solution (Tabatabai and Bremner 1972). The activities of fluorescein diacetate (FDA) and acid phosphatase enzyme hydrolysis were estimated by spectrophotometry at wavelengths of 490 and $410 \mathrm{~nm}$, respectively (Dick et al. 1996). Soil extract was evaluated in a spectrophotometer at the wavelength of $410 \mathrm{~nm}$ to 
determine the activity of the enzyme $\beta$-glucosidase (Tabatabai 1994) with a curve for quantification obtained from standard solution of $1000 \mathrm{mg} \mathrm{mL}^{-1}$ of p-nitrophenol.

Basal respiration was determined from $20 \mathrm{~g}$ of soil with moisture adjusted to $60 \%$ (Alef and Nannipieri 1995). Substrate-induced respiration was determined similarly to basal respiration, and sucrose solution $(0.05 \%)$ was added to the soil as a readily available carbon source, incubated with $\mathrm{NaOH}$-containing vials (changed at each reading) in a hermetically sealed container. Three readings were performed every three hours, and a fourth reading was performed 22 hours after the initial incubation.

TERRAIN ATTRIBUTES AND ITS RELATION TO MICROBIOLOGICAL INDICATORS OF SOIL QUALITY

In order to correlate the soil biological attributes with topographic factors, a Digital Elevation Model (DEM) with $3 \mathrm{~m}$ of spatial resolution was created through the Topo To Raster tool of ArcGIS 10.3 (ESRI) software, from contour lines of $1 \mathrm{~m}$ of vertical distance between them. In a DEM, each pixel represents the altitude of each local of the landscape in a continuous way. From this DEM, topographic attributes were generated in SAGA GIS software (Conrad et al. 2015), including: slope, aspect, topographic wetness index (Beven and Kirkby 1979), altitude above the channel network, hillshade, cross-sectional and longitudinal curvatures, and Geomorphons (Jasiewicz and Stepinski 2013), which segments the landscape in up to 10 pedoforms, allowing associations with sites of erosion and deposition of water and sediments. These digital terrain models have been extensively used in works relating them to soil attributes (Adhikari et al. 2013, Pelegrino et al. 2016, Silva et al. 2016b, Taghizadeh-Mehrjardi et al. 2015, Pinto et al. 2017). From the topographic information, the values of each terrain attribute, as well as the altitudes of the DEM were extracted at each of the 16 sampling points and they were used to evaluate the effects of the different hillslope positions on the soil microbiological attributes.

\section{STATISTICAL ANALYSIS}

The SISVAR software (Ferreira 2014) was used to perform normality tests, followed by analysis of variance (ANOVA) and Scott-Knott test (5\%), when the data were normally distributed and Kruskal Wallis test when they did not fit this distribution. Pearson correlation analysis was performed to verify the influence of topographic factors on the microbiological attributes of the analyzed soils.

To evaluate the most important topographic attributes to explain the variation of microbiological attributes, the random forest algorithm was used in software R, randomForest package (Liaw and Wiener 2015), with 1000 trees of the model (ntrees), 5 variables in each node (nodesize) and one third of the total number of samples in each tree (mtry), as suggested by Liaw and Wiener (2002) for random forest regression.

\section{RESULTS AND DISCUSSION}

\section{SOIL CHARACTERIZATION}

The four positions evaluated in the hillslope (Figure 2) belong to the Neosols (Entisols in Soil Taxonomy), a soil order characterized by being weakly developed, not presenting a B horizon. However, the point with the lowest altitude, near the watercourse, was classified within the suborder of Fluvic Neosols (Fluvents), formed from the deposition of alluvial and colluvial sediments, while the other three places, in higher altitudes, are Regolithic Neosols (Orthents) (Table I). In spite of this difference in the suborders, the chemical and physical attributes evaluated were similar (Table I), being these soils, in general, poor in nutrients and of sandy loam texture, as a reflection of quartzite rocks that form this Bocaina Mountain Range (Curi 


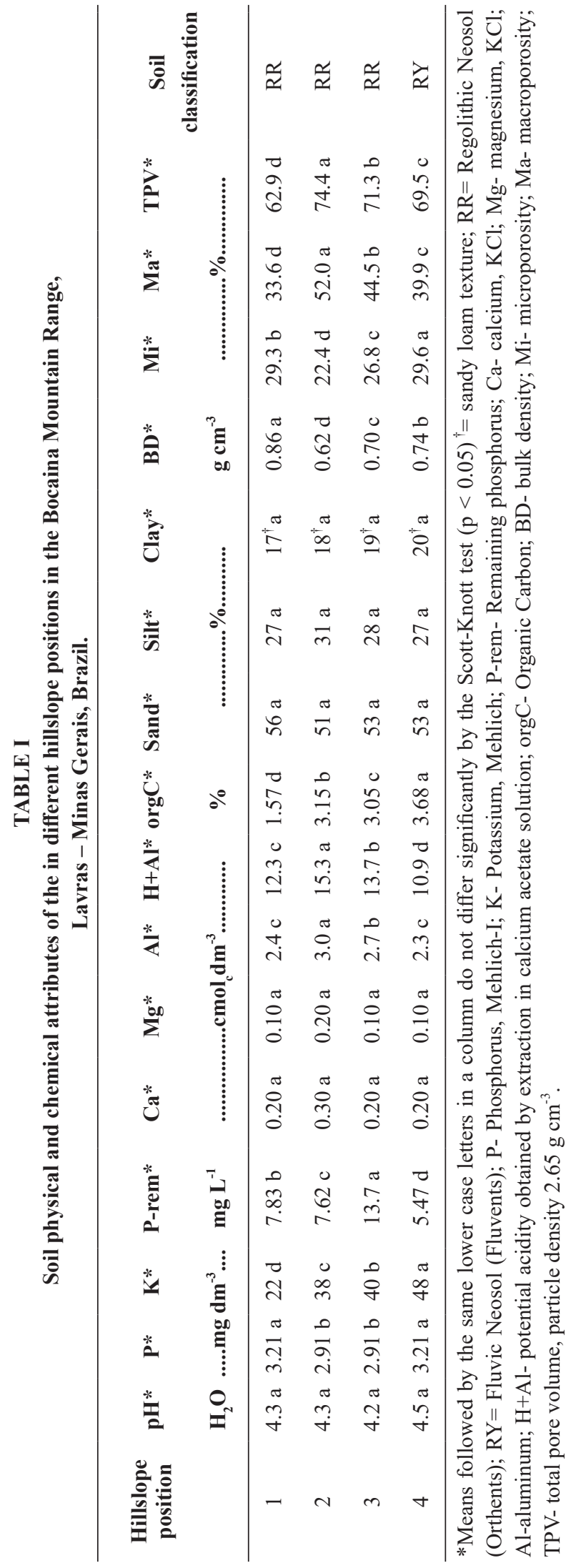

et al. 1990). However, the organic matter contents varied from medium to good, being the highest values found in the Fluvic Neosol, probably due to the greater proximity to the watercourse, making it difficult to be decomposed by microorganisms (Resende et al. 2014) since it is a depositional surface. Similar behavior of organic matter contents was found by Menezes et al. (2016) on a watershed in the state of Minas Gerais, Brazil.

Among the evaluated points, three are located on erosional positions and only the point at the lowest altitude on the hillslope is on deposition surface, besides showing variations in the slope and in the topographic wetness index, the point closest to the watercourse being the one with highest water accumulation, as expected (Figure 2, Table II). Although the hillslope presents small concavities (ravines), which modifies this general trend (see point 2, where topographic wetness index is greater than point 3 ), the low moisture content of point 3 can be explained by its greater slope $(67 \%)$ that prevents the accumulation of water.

\section{SOIL MICROBIOLOGICAL ATTRIBUTES}

The activity of the urease and FDA enzymes did not differ between the evaluated hillslope points, whereas the acid phosphatase was lower at point 3 and the $\beta$-glucosidase enzyme was higher at the lowest point (Figure 3). Although they are considered good indicators of soil quality by presenting variations when there are changes in soil use and management, the activity of soil enzymes is also sensitive to variations within the same environment, such as temperature and geographic location (Cardoso et al. 2013, Burns et al. 2013).

While the activity of urease and FDA enzymes were more stable with respect to the variation in hillslope position, even in similar soils and under the same vegetation, the variation of the activity of acid phosphatase and $\beta$-glucosidase shows greater sensitivity of these indicators. Since the enzyme 

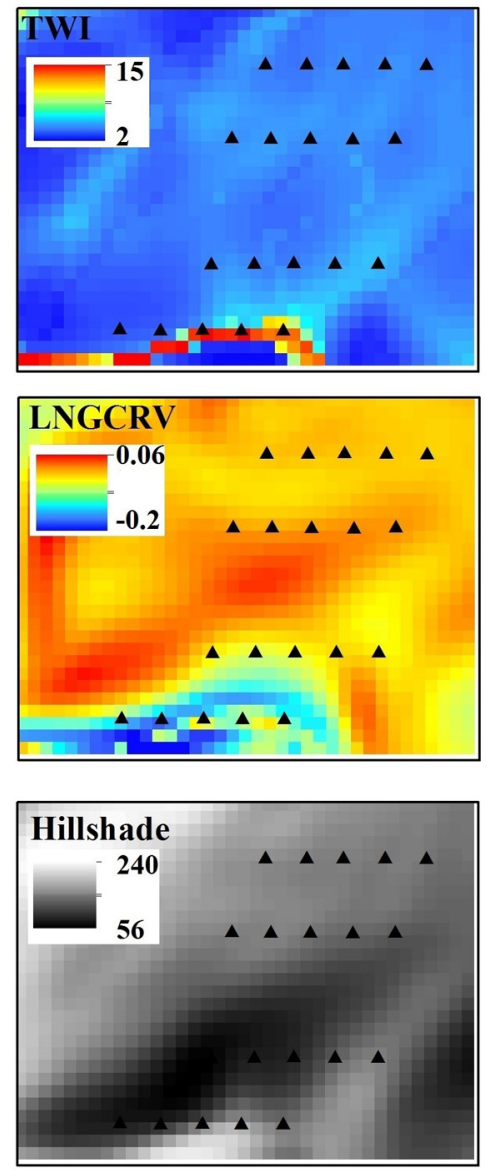
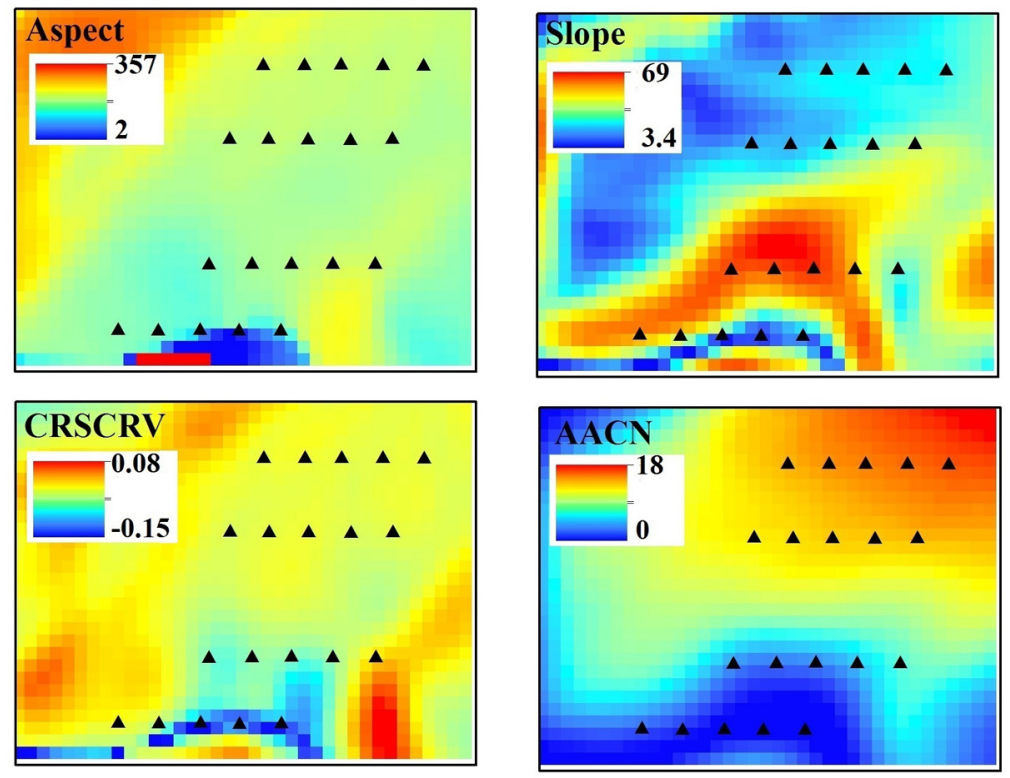

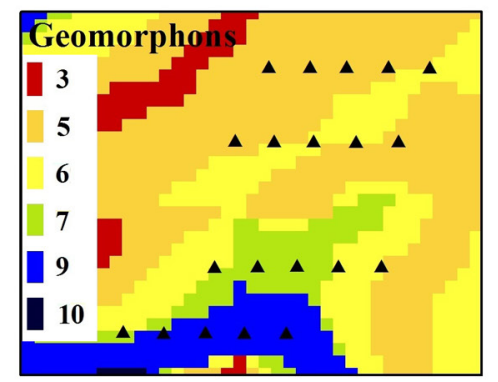

Figure 2 - Terrain attributes obtained from a Digital Elevation Model of 3 m resolution.

TWI - topographic wetness index; LNGCRV - longitudinal curvature; CRSCRV - cross sectional curvature; AACN altitude above the channel network; 3 - Ridge, 5 - Spur, 6 - Slope, 7 - Hollow, 9 - Valley, 10 - Pit.

TABLE II

Terrain attributes in different hillslope positions in the Bocaina Mountain Range, in Lavras - Minas Gerais, Brazil.

\begin{tabular}{ccccccc}
\hline $\begin{array}{c}\text { Hillslope } \\
\text { position }\end{array}$ & Altitude (m) & Slope (\%) & $\begin{array}{c}\text { Altitude above the } \\
\text { channel network (m) }\end{array}$ & $\begin{array}{c}\text { Topografic } \\
\text { wetness index }\end{array}$ & Geomorphons & Hillshade \\
\hline 1 & 1127.28 & 28.4 & 14.9 & 1.96 & 5 (Erosional) & 150 \\
2 & 1121.84 & 27.0 & 12.8 & 1.98 & 6 (Erosional) & 146 \\
3 & 1106.44 & 67.0 & 3.5 & 1.93 & 7 (Erosional) & 84 \\
4 & 1100.25 & 16.4 & 0.53 & 4.79 & 9 (Depositional) 149 \\
\hline
\end{tabular}

$\beta$-glucosidase promotes the hydrolysis of cellulose cellobiose residues (Deng and Tabatabai 1994), the higher activity of this enzyme on the depositional place (point 4) can be related to the greater amount of residues that are deposited there originated both from the upper points on the hillslope and from alluvial sediments.
The basal respiration (Figure 4) did not differ between the positions in the landscape, while the induced one was greater in points 2 and 3 , intermediate in the hillslope. The activity of soil microorganisms can be determined by their respiration and can respond rapidly to changes that occur in the environment (Couto et al. 2016). The 

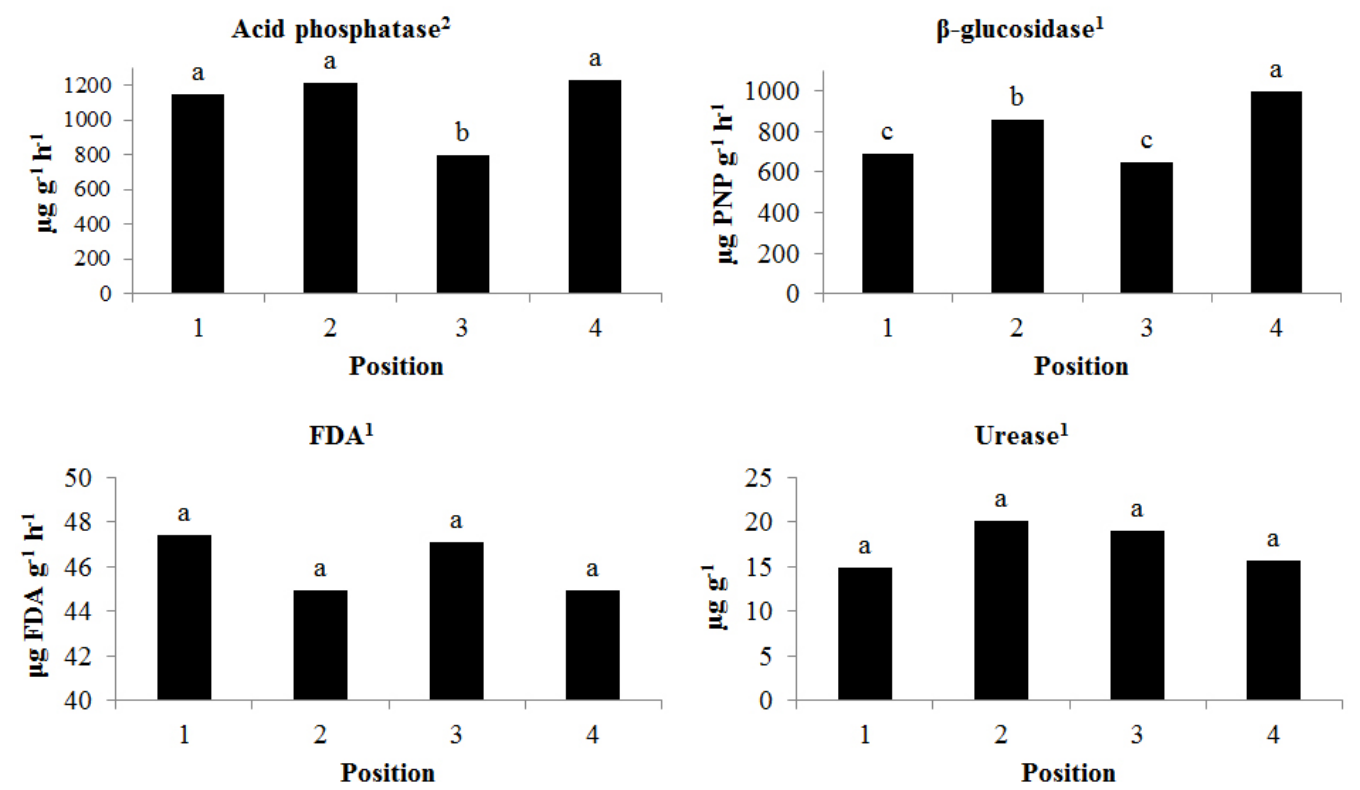

Figure 3 - Enzymatic activity in soil samples $(0$ to $20 \mathrm{~cm})$ collected in different hillslope positions in the Bocaina Mountain Range, in Lavras - Minas Gerais, Brazil. 1 - upper backslope; 2 - middle backslope; 3 - lower backslope; 4 - footslope.

Means followed by the same letter do not differ statistically, according to ${ }^{1}$ Scott-Knott or ${ }^{2}$ Kruskal-Wallis test $(\mathrm{p}<0.05)$.

samples that were collected under native vegetation with very little human interference, presented similarity in basal respiration, which was expected since in an equilibrium environment the activity of the microbiota tends to remain stable.

On the other hand, the increased respiration of the microbial biomass at the intermediate points on the hillslope in response to the added substrate shows that, even in stable ecosystems, the response of the microorganisms may be different. Differences in respiration induced over time were also observed (Figure 5). The evolution of respiration alone tends to be similar, but in the intermediate positions of the hillslope (points 2 and $3)$, the activity that generated the difference noted in Figure 4 was noticed between 3 and 6 hours, showing the greater adaptability of the microbiota of these positions in degrading the substrate. In the final evaluations, after 9 and 22 hours after the induction of respiration by the substrate, respiration stabilized, presenting close values.
The mycorrhizal colonization on the collected roots did not differ statistically among the hillslope positions, with an overall mean of $26.7 \%$ of colonization (Figure 6). AMF spore density was higher at points 1 and 2, located at the higher elevation parts of the hillslope. Freitas et al. (2014) found variation in AMF spore density along a topographic gradient in central Amazonia. Similarly, Silva et al. (2014), evaluating spore density in environments in the Brazilian semi-arid region, obtained a higher density of spores in dry forest than in rainforest, in both dry and wet seasons, indicating that the topographic factor and soil moisture can affect the density of spores, thus being expected, in positions under similar conditions, higher density of spores in drier positions. The highest altitude in relation to the drainage network in points 1 and 2 (Table II) avoid the accumulation of water in these places, favoring drainage to the lowest places of the hillslope. This better drainage conditions can cause the plants in association with 


\section{Basal respiration ${ }^{2} 3$}

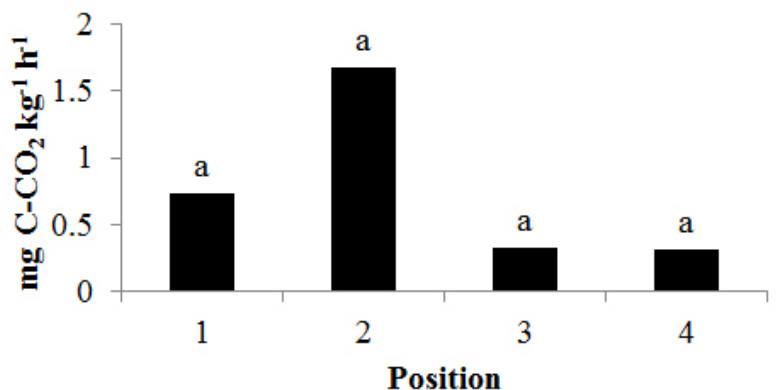

Induced respiration ${ }^{1}$

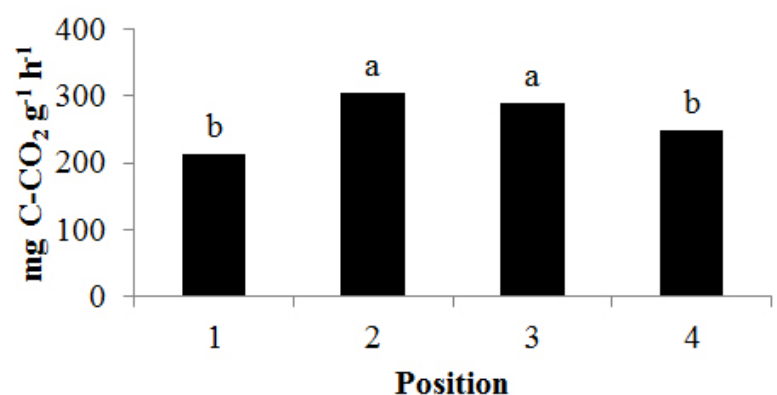

Figure 4 - Microbial respiration in soil samples $(0$ to $20 \mathrm{~cm})$ in different hillslope positions in the Bocaina Mountain Range, in Lavras - Minas Gerais, Brazil. 1 - upper backslope; 2 - middle backslope; 3 - lower backslope; 4 - footslope.

Means followed by the same letter do not differ from one another by the ${ }^{1}$ Scott-Knott or ${ }^{2}$ Kruskal-Wallis test $(\mathrm{p}<0.05)$; ${ }^{3}$ transformed data per $\log (\mathrm{x})$.

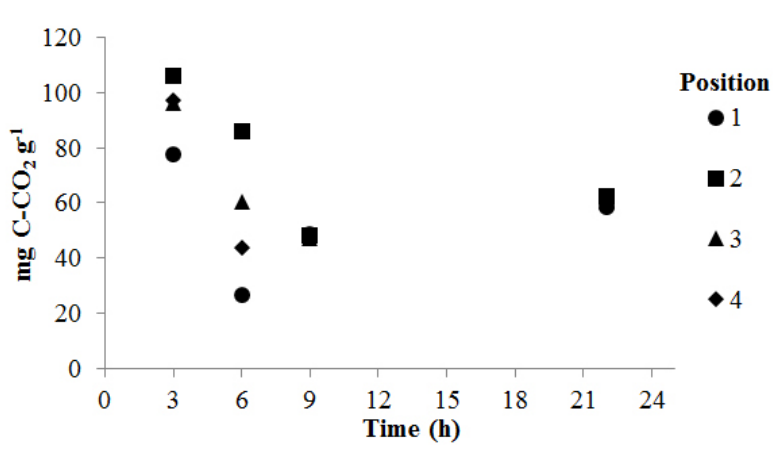

Figure 5 - Evolution of substrate-induced respiration from different hillslope positions in the Bocaina Mountain Range, in Lavras - Minas Gerais, Brazil. 1 - upper backslope; 2 - middle backslope; 3 - lower backslope; 4 - footslope.

AMF in these positions to suffer more water deficit, which is a stimulus to spore production, justifying the higher density found there, which is improved in soils with greater amounts of sand, such as the ones of this study. The density of actinobacteria, the MPN of native rhizobia and free-living $\mathrm{N}_{2}$-fixing bacteria in JNFB medium did not differ statistically between the positions on the hillslope (Figure 7).

The NN, NDM and SDM of cowpea inoculated with soil suspension did not show a significant difference between the hillslope positions (Figure 6). This shows that the bacteria present had the same efficiency in nodulate and fix $\mathrm{N}_{2}$ for the plant in question.
The density of total bacteria, phosphate solubilizers, ammonifiers, and free-living $\mathrm{N}_{2}$ fixing bacteria in NFB were higher in points 2 and 4 , the same points where the topographic wetness index was higher (Table II). In contrast, the fungal population was higher in the positions with lower topographic wetness index (Figure 7). It is known that the populations of fungi are larger in drier periods, while those of bacteria have higher density in wetter periods (Rodrigues et al. 2011). In this study, it was observed that in the same dry period, the variation in the topographic wetness index caused by the hillslope led to differences in the density of fungi in positions with lower topographic wetness index and higher density of bacteria with the increase of this index.

\section{IMPORTANCE OF TOPOGRAPHIC ATTRIBUTES TO EXPLAIN MICROBIOLOGICAL ATTRIBUTES}

Among the microbiological attributes analyzed, the activity of the enzymes $\beta$-glucosidase, acid phosphatase, the activity of the FDA besides the MPN of native rhizobia and free-living $\mathrm{N}_{2}$-fixing detected in NFB medium showed correlations with one or more topographic attributes (Table III). In contrast, the activity of the urease enzyme, freeliving $\mathrm{N}_{2}$-fixing bacteria grown in JNFB medium, ammonifiers, actinobacteria, total fungi, in addition 

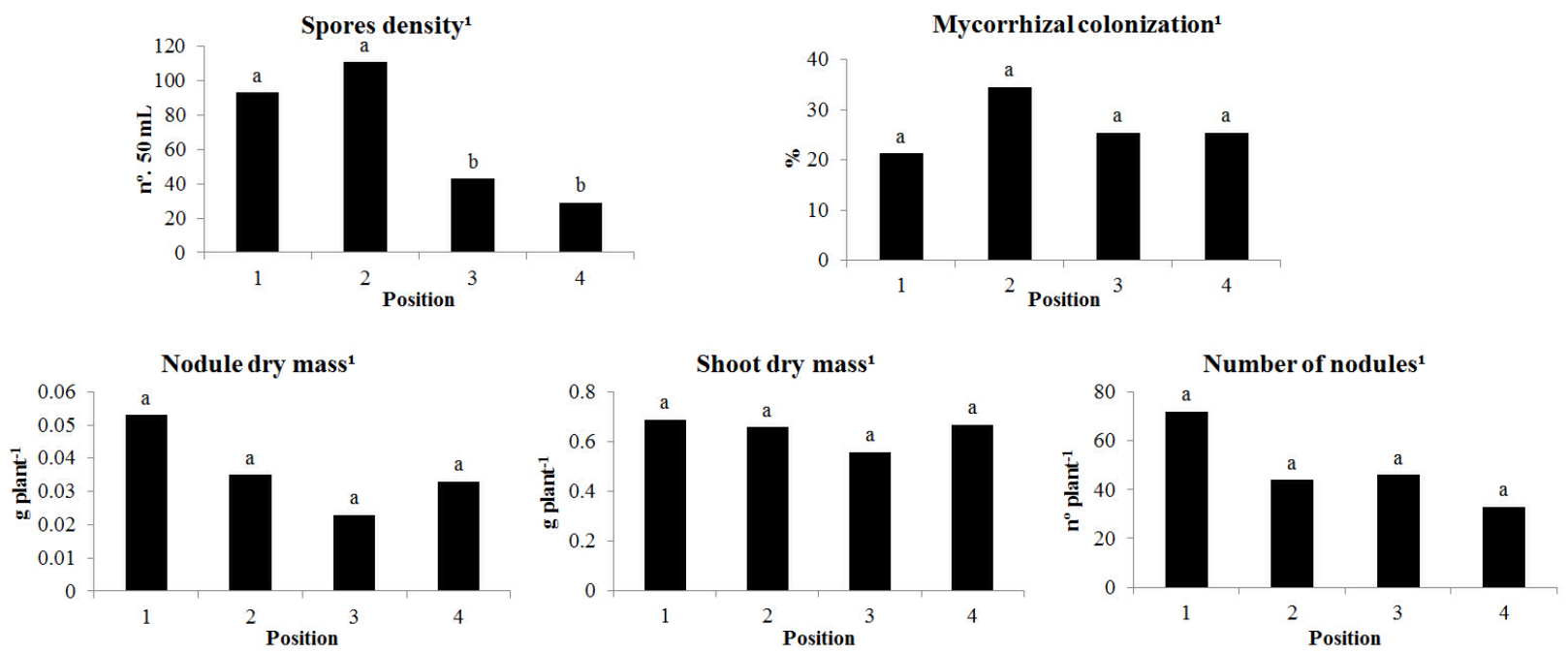

Figure 6 - Density of spores of mycorrhizal arbuscular fungi and mycorrhizal colonization on roots of native plants from different hillslope positions in the Bocaina Mountain Range, Lavras - Minas Gerais, Brazil, and number of nodules, dry mass of nodules and aerial part of the symbiosis experiment between native nitrogen fixing bacteria and cowpea inoculated with field soil and conducted under greenhouse conditions. 1 - upper backslope; 2 - middle backslope; 3 - lower backslope; 4 - footslope.

Means followed by the same letter do not differ statistically by ${ }^{1}$ Scott-Knott test $(\mathrm{p}<0.05)$.
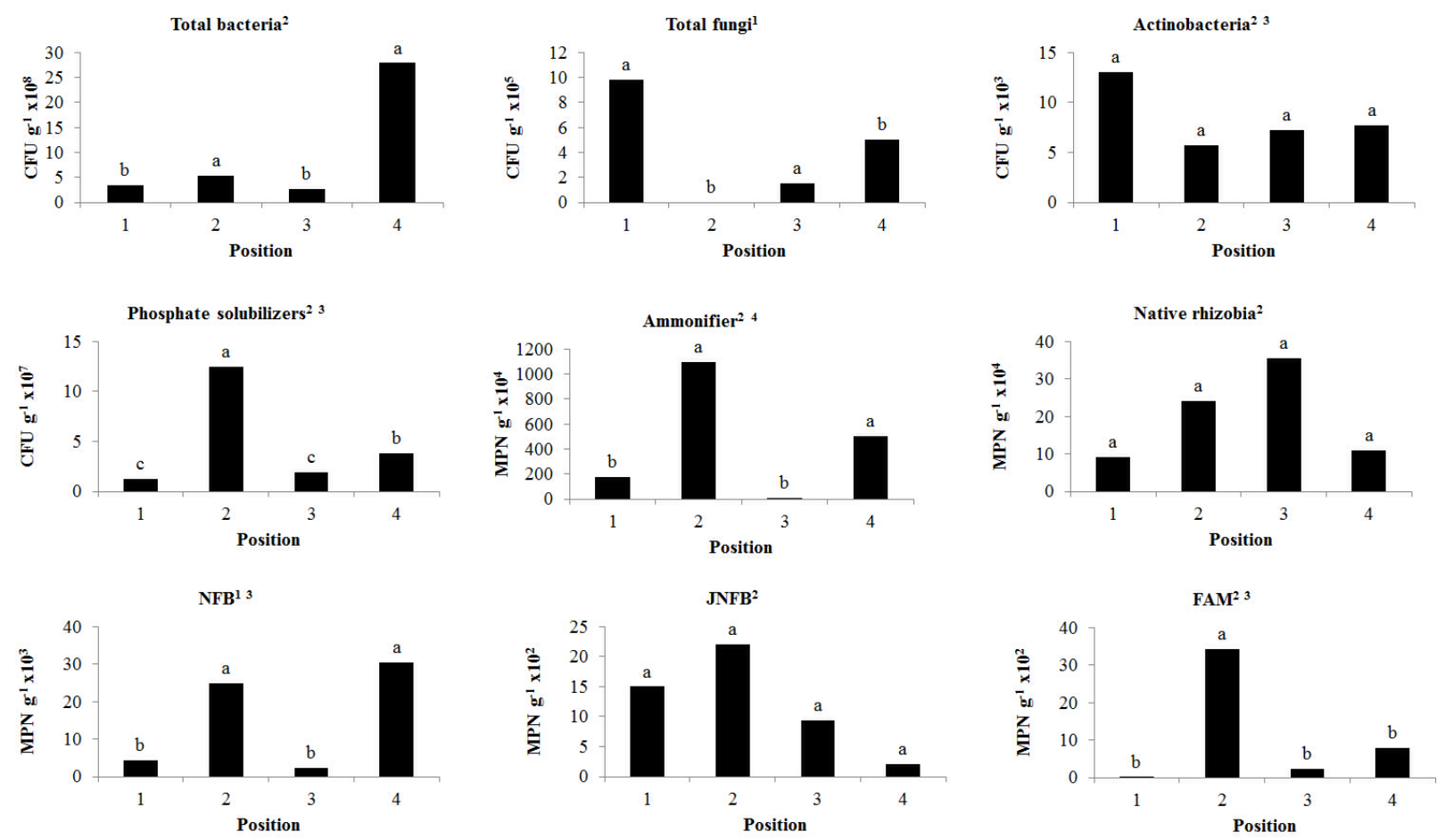

Figure 7 - Total bacterial counts, total fungi, actinobacteria, phosphate solubilizers, ammonifiers, native rhizobia and free-living $\mathrm{N}_{2}$-fixing bacteria from different hillslope positions in the Bocaina Mountain Range, in Lavras - Minas Gerais, Brazil. 1 - upper backslope; 2 - middle backslope; 3 - lower backslope; 4 - footslope.

Means followed by the same letter do not differ from each other, according to the test of ${ }^{1}$ Scott-Knott and ${ }^{2}$ Kruskal-Wallis tests ( $\mathrm{p}$ $<0.05)$ nd - not determined; ${ }^{3}$ data transformed by $\log (\mathrm{x}) ;{ }^{4}$ data transformed by square root of $\mathrm{Y}$. 
TABLE III

Coefficient of correlation between microbiological attributes and topographic attributes of a hillslope in the Bocaina Mountain Range, in Lavras - Minas Gerais, Brazil.

\begin{tabular}{ccccccccc}
\hline & Gm & TWI & LNGCRV & CRSCRV & AACN & Hillshade & Slope & Altitude \\
\hline Acid phosphatase & $0.192^{\text {ns }}$ & $0.333^{\text {ns }}$ & $-0.108^{\text {ns }}$ & $-0.138^{\text {ns }}$ & $0.183^{\text {ns }}$ & $0.545^{*}$ & $-0.724^{* *}$ & $0.175^{\text {ns }}$ \\
FDA activity & $-0.089^{\text {ns }}$ & $-0.434^{\text {ns }}$ & $-0.113^{\text {ns }}$ & $0.225^{\text {ns }}$ & $0.0002^{\text {ns }}$ & $-0.429^{\text {ns }}$ & $0.528^{*}$ & $0.0203^{\text {ns }}$ \\
$\beta$-glucosidase & $0.555^{*}$ & $0.430^{\text {ns }}$ & $-0.539^{*}$ & $-0.328^{\text {ns }}$ & $-0.39^{\text {ns }}$ & $0.0847^{\text {ns }}$ & $-0.272^{\text {ns }}$ & $-0.398^{\text {ns }}$ \\
FLNFB & $0.349^{\text {ns }}$ & $0.567^{*}$ & $0.0716^{\text {ns }}$ & $-0.837^{* *}$ & $-0.182^{\text {ns }}$ & $0.207^{\text {ns }}$ & $-0.387^{\text {ns }}$ & $-0.237^{\text {ns }}$ \\
Native rhizobia & $0.558^{*}$ & $0.549^{*}$ & $-0.502^{*}$ & $-0.387^{\text {ns }}$ & $-0.578^{*}$ & $0.133^{\text {ns }}$ & $-0.18^{\text {ns }}$ & $-0.612^{*}$ \\
\hline
\end{tabular}

FLNFB: free-living $\mathrm{N}_{2}$-fixing bacteria; Gm: Geomorphons; TWI: topographic wetness index; LNGCRV: longitudinal curvature; CRSCRV: cross sectional curvature; AACN: altitude above the channel network. ${ }^{*} \leq 0.05 ;{ }^{* *} \mathrm{p} \leq 0.01 ;{ }^{\text {ns }}$ : not significant.

TABLE IV

Most important terrain attribute $(\mathrm{AT}+\mathrm{I})$ and less important terrain attribute (AT - I) to explain variation in microbiological attributes urease (Ure), actinobacteria (Act), Ammonifiers (Ammon), activity of the FDA (FDA), $\beta$-glucosidase ( $\beta$ ), free-living $\mathrm{N}_{2}$-fixing bacteria detected from FAM (Df) medium, NFB (Dn) and JNFB (Dj), phosphatase

(Pho), total fungi (TF), most probable number of native rhizobia (MPN), basal respiration (BR), substrate-induced respiration (RI), and percentage of this variance explained by terrain attributes (VABET).

\begin{tabular}{|c|c|c|c|c|c|c|c|c|c|c|c|c|c|}
\hline & Ure & Act & Ammon & FDA & $\beta$ & Df & Pho & TF & Dj & Dn & MPN & BR & RI \\
\hline $\begin{array}{c}\text { VABET } \\
(\%)\end{array}$ & -31.39 & 6.53 & 28.42 & 12.06 & 31.96 & -29.33 & 15.55 & -19.66 & -52.05 & -48.45 & 11.27 & -37.56 & 22.1 \\
\hline $\mathrm{AT}+\mathrm{I}$ & SL & Alt & LNGCRV & SL & LNGCRV & AADL & SL & Alt & Alt & LNGCRV & TWI & GM & Alt \\
\hline AT - I & CRSCRV & CRSCRV & TWI & CRSCRV & HS & CRSCRV & TWI & GM & LNGCRV & TWI & HS & LNGCRV & HS \\
\hline
\end{tabular}

TWI: topographic wetness index; LNGCRV: longitudinal curvature; CRSCRV: cross sectional curvature; AADL: altitude above the drainage line; HS: hillshade; Alt: altitude; GM: geomorphons; SL: slope.

to basal respiration, spore density and mycorrhizal colonization did not present a significant correlation with the evaluated topographic attributes.

The MPN of native rhizobia was the biological attribute that correlated with the highest number of terrain attributes (five), being them Geomorphons, topographic wetness index, longitudinal curvature, altitude above the channel network and altitude. The activity of the FDA correlated only with slope. On the other hand, among the terrain attributes, Geomorphons, slope, topographic wetness index and longitudinal curvature were correlated with two biological attributes.

The hillshade variable, which refers to the luminosity in the position (the higher the hillshade, the more illuminated the position by sunlight), was correlated with phosphatase, being lower in point 3 , which presents lower illumination. It is known that microbial diversity may vary depending on sunlight exposure (Griffiths and Philippot 2013). In this way, the soil organisms responsible for producing phosphatase are negatively influenced when the position is more shaded.

Regarding the importance of the terrain attributes that best explain the variations in biological attributes determined by the random forest algorithm, the $\beta$-glucosidase enzyme was the one that presented the highest percentage of variation dependent on terrain attributes (Table IV), followed by ammonifiers and induced respiration. The terrain attributes that best explain the variation of these three biological attributes are altitude, slope and longitudinal curvature. Among these, slope and longitudinal curvature were also correlated with soil biological attributes (Table III).

Although several biological attributes have presented variation explained by terrain attributes, basal respiration, urease enzyme activity, AMF 
spore density, mycorrhizal colonization, bacteria and fungi, phosphate solubilizers, and detected freeliving $\mathrm{N}_{2}$-fixing bacteria in JNFB and FAM, did not present variation explained by terrain attributes, both in the analysis by random forest and in the analysis of correlation, showing the insensitivity of these microbiological attributes to variations along a hillslope.

\section{CONCLUSIONS}

The variation in the topographic wetness index caused by the topography generates different responses in density of microorganisms of distinct groups in soil. The hillslope evaluated at Bocaina Mountain Range presents microorganisms that perform different functions in the maintenance of the quality of the soil and some groups of biological indicators of soil quality vary according to topographic factors, mainly altitude, slope and longitudinal curvature.

The biological indicators of soil quality that were most influenced by variations in the terrain attributes along the hillslope were the activity of the enzymes $\beta$-glucosidase, phosphatase, the FDA, the MPN of native rhizobia and free-living $\mathrm{N}_{2}$-fixing bacteria detected in NFB medium. In contrast, the urease enzyme, basal respiration, total fungi, and free-living $\mathrm{N}_{2}$-fixing bacteria detected in JNFB and FAM are less sensitive, therefore, they are more indicated to evaluate sites with greater terrain variability.

Future studies are needed to verify the influence of topographic attributes on different relief, climatic, pedological and vegetation conditions. Such studies may better elucidate whether the behavior of these microbiological indicators and topographic attributes will be similar to the behavior found in this study, thus helping select the best microbiological indicators for different conditions.

\section{ACKNOWLEDGMENTS}

The authors are grateful to the Coordenação de Aperfeiçoamento de Pessoal de Nível Superior (CAPES), Fundação de Amparo à Pesquisa do Estado de Minas Gerais (FAPEMIG) and to the Conselho Nacional de Desenvolvimento Científico e Tecnológico (CNPq) for financial support, fellowships and scholarships.

\section{AUTHOR CONTRIBUTIONS}

Anita Fernanda dos Santos Teixeira contributed to soil sample, laboratory and data analysis, land attribute collection and processing, and scientific writing. Jacqueline Savana Silva, Laíze Aparecida Ferreira Vilela, Patrícia Freitas Costa, Elaine Martins da Costa, Amanda Azarias Guimarães and Jessé Valentim dos Santos, contributed to soil sample, laboratory and data analysis, and scientific writing. Professor Sérgio Henrique Godinho Silva contributed to the project idealization, terrain attribute collection and processing, data analysis and scientific writing and Professor Marco Aurélio Carbone Carneiro and Professor Fatima Maria de Souza Moreira contributed to the project coordination and idealization, soil sample, laboratory analysis, data analysis and scientific writing.

\section{REFERENCES}

ADHIKARI K, KHEIR RB, GREVE MB, BØCHER PK, MALONE BP, MINASNY B, MCBRATNEY AB AND GREVE MH. 2013. High-Resolution 3-D Mapping of Soil Texture in Denmark. Soil Sci Soc of Am J 77(3): 860-876.

ALEF K AND NANNIPIERI P. 1995. Methods in applied soil microbiology and biochemistry. Academic Press, London, $576 \mathrm{p}$.

ALVARES CA, STAPE JL, SENTELHAS PC, DE MORAES GONÇALVES JL AND SPAROVEK G. 2013. Köppen's climate classification map for Brazil. Meteorol Z 22(6): 711-728.

ALVAREZ V VH AND FONSECA DM. 1990. Definição de doses de fósforo para a determinação da capacidade máxima de adsorção de fosfato e para ensaios de casa de vegetação. Rev Bras Cienc Solo 14: 49-55. 
BEVEN KJ AND KIRKBY MJ. 1979. A physically based, variable contributing area model of basin hydrology / Un modèle à base physique de zone d'appel variable de l'hydrologie du bassin versant. Hydrol Sci 24(1): 43-69.

BURNS RG, DEFOREST JL, MARXSEN J, SINSABAUGH RL, STROMBERGER ME, WALLENSTEIN MD, WEINTRAUB MN AND ZOPPINI A. 2013. Soil enzymes in a changing environment: Current knowledge and future directions. Soil Biol Biochem 58: 216-234.

CARDOSO EJBN, VASCONCELLOS RLF, BINI D, MIYAUCHI MYH, SANTOS CA DOS, ALVES PRL, PAULA AM, NAKATANI AS, PEREIRA JM AND NOGUEIRA MA. 2013. Soil health: looking for suitable indicators. What should be considered to assess the effects of use and management on soil health? Sci Agr 70(4): 274289.

CONRAD O, BECHTEL B, BOCK M, DIETRICH H, FISCHER E, GERLITZ L, WEHBERG J, WICHMANN V AND BÖHNER J. 2015. System for Automated Geoscientific Analyses (SAGA) v. 2.1.4. Geoscientific Model Development 8(7): 1991-2007.

COUTO GM, EISENHAUER N, BATISTA DE OLIVEIRA E, CESARZ S, PATRIOTA FELICIANO AL AND MARANGON LC. 2016. Response of soil microbial biomass and activity in early restored lands in the northeastern Brazilian Atlantic Forest. Restoration Ecology 24(5): 609-616.

CURI N, LIMA JM, ANDRADE H AND GUALBERTO V. 1990. Geomorfologia, física, química e mineralogia dos principais solos da região de Lavras (MG). Ciência e Prática 14(3): 297-307.

DALANESI PE, OLIVEIRA-FILHO AT AND FONTES MAL. 2004. Flora e estrutura do componente arbóreo da floresta do Parque Ecológico Quedas do Rio Bonito, Lavras, MG, e correlações entre a distribuição das espécies e variáveis ambientais. Acta Bot Bras 18(4): 737-757.

DENG SP AND TABATABAI MA. 1994. Cellulase activity of soils. Soil Biol Biochem 26(10): 1347-1354.

DICK RP, BREAKWELL DP AND TURCO RF. 1996. Soil enzyme activities and biodiversity measurements as integrative microbiological indicators. In: Doram JW and Jones AJ (Eds), Methods for Assessing Soil Quality. Soil Science Society of America, Madison, p. 247-271.

DÖBEREINER J, BALDANI VLD AND BALDANI JI. 1995. Como isolar e identificar bactérias diazotróficas de plantas não-leguminosas. Empresa Brasileira Pesquisa Agropecuária, Seropédica, Empresa Brasileira Pesquisa Agropecuária - Centro Nacional de Pesquisa Agrobiologia, Brasília, 60 p.

DONAGEMA GK, CAMPOS DVB DE, CALDERANO SB, TEIXEIRA WG AND VIANA JHM. 2011. Manual de Métodos de Análise de Solo. ( $2^{\mathrm{a}}$ ). Embrapa Solos, Rio de Janeiro, $230 \mathrm{p}$.
DORAN W AND PARKIN T. 1994. Defining and assessing soil quality. In: Doran JW, Coleman DC, Bezdicek DF and Stewart BA (Eds), Defining Soil Quality for a Sustainable Environment. Madison: Soil Science Society of America Proceedings, p. 3-21.

ESCH EH, LIPSON D AND CLELAND EE. 2017. Direct and indirect effects of shifting rainfall on soil microbial respiration and enzyme activity in a semi-arid system. Plant Soil 411(1-2): 333-346.

FAUCON M-P, HOUBEN D AND LAMBERS H. 2017. Plant Functional Traits: Soil and Ecosystem Services. Trends Plant Sci 22(5): 385-394.

FERREIRA DF. 2014. Sisvar: a Guide for its Bootstrap procedures in multiple comparisons. Ciênc e Agrotec 38(2): 109-112.

FREITAS RO, BUSCARDO E, NAGY L, DOS SANTOS MACIEL AB, CARRENHO R AND LUIZÃO RCC. 2014. Arbuscular mycorrhizal fungal communities along a pedohydrological gradient in a Central Amazonian terra firme forest. Mycorrhiza 24(1): 21-32.

GERDEMANN JW AND NICOLSON TH. 1963. Spores of mycorrhizal Endogone species extracted from soil by wet sieving and decanting. Trans Br mycol Soc 46(2): 235-244.

GRIFFITHS BS AND PHILIPPOT L. 2013. Insights into the resistance and resilience of the soil microbial community. FEMS Microbiol Ver 37(2): 112-129.

JASIEWICZ J AND STEPINSKI TF. 2013. Geomorphons - a pattern recognition approach to classification and mapping of landforms. Geomorphology 182: 147-156.

JENKINS WR. 1964. A rapid centrifugal-flotation technique for separating nematodes from soil. Plant Dis 48: 692.

JENNY H. 1941. Factors of soil formation: A system of quantitative Pedology. New York: McGraw-Hill Book, $281 \mathrm{p}$.

KIM S. 2016. Time series modeling of soil moisture dynamics on a steep mountainous hillside. J Hydrol 536: 37-49.

KOSKE RE AND GEMMA JN. 1989. A modified procedure for staining roots to detect VA mycorrhizas. Mycol Res 92(4): 486-488.

LIAW A AND WIENER M. 2002. Classification and Regression by randomForest. R News 2: 18-22.

LIAW A AND WIENER M. 2015. Package 'randomForest'. R Development Core Team.

MAGALHÃES FM, BALDANI JI, SOUTO SM, KUYKENDALL JR AND DOBEREINER J. 1983. A new acid- tolerant Azospirillum species. An Acad Bras de Cienc 55: 417-430.

MARTIN JP. 1950. Use of acid, rose bengal, and streptomycin in the plate method for estimating soil fungi. Soil Sci 69: 215-232.

MCBRATNEY AB, MENDONÇA SANTOS ML AND MINASNY B. 2003. On digital soil mapping. Geoderma 117(1-2): 3-52. 
MCKAY J, GRUNWALD S, SHI X AND ANDLONG RF. 2010. Evaluation of the Transferability of a KnowledgeBased Soil-Landscape Model. In: Boettinger JL, Howell DW, Moore AC, Hartemink AE and Kienast-Brown S (Eds), Digital Soil Mapping: Bridging Research, Environmental Application, and Operation. London:Springer, p. 165-177.

MCLEAN EO, HEDDLESON MR, BARTLETT RJ AND HOLOWAYCHUK N. 1958. Aluminum in Soils: I. Extraction Methods and Magnitudes in Clays and Ohio Soils. Soil Sci Soc Am Jo 22(5): 382 p.

MEHLICH A. 1953. Determination of P, Ca, Mg, K, Na and $\mathrm{NH}_{4}$. North Carolina Soil Testing Division, Raleigh, $195 \mathrm{p}$.

MENEZES MD DE, SILVA SHG, MELLO CR DE, OWENS PR AND CURI N. 2016. Spatial prediction of soil properties in two contrasting physiographic regions in Brazil. Sci Agric 73(3): 274-285.

MOORE ID, GESSLER PE, NIELSEN GAAND PETERSON GA. 1993. Soil Attribute Prediction Using Terrain Analysis. Soil Sci Soc Am J 57(2): 443-452.

MOREIRA FMS AND CAMPOS CRA. 2013. Microorganismos. In: Moreira FMS, Cares JE, Zanetti R and Stürmer SL (Eds), O Ecossistema Solo: Componentes, Relações Ecológicas e Efeitos Na Produção Vegetal. Lavras: Editora UFLA, p. 201-222.

MOREIRA FMS, CARES JE, ZANETTI R AND STÜRMER SL. 2013. O ecossistema solo: componentes, relações ecológicas e efeitos na produção vegetal. In: Moreira FMS, Cares JE, Zanetti R and Stürmer SL (Eds), O Ecossistema Solo: Componentes, Relações Ecológicas e Efeitos na Produção Vegetal. Lavras: Editora UFLA, p. 139-168.

MOREIRA FMS, SIQUEIRA JO AND BRUSSAARD L. 2006. Soil biodiversity in Amazonian and other Brazilian ecosystems. London: CABI Publishing, $280 \mathrm{p}$.

OCHOA PA, FRIES A, MEJÍA D, BURNEO JI, RUÍZSINOGA JD AND CERDÀ A. 2016. Effects of climate, land cover and topography on soil erosion risk in a semiarid basin of the Andes. Catena 140: 31-42.

OLIVEIRA-FILHO AT AND FONTES MAL. 2000. Patterns of Floristic Differentiation among Atlantic Forests in Southeastern Brazil and the Influence of Climate. Biotropica 32(4b): 793-810.

PELEGRINO MHP, SILVA SHG, MENEZES MD DE, SILVA E DA, OWENS PR AND CURI N. 2016. Mapping soils in two watersheds using legacy data and extrapolation for similar surrounding areas. Ciênc e Agrotec 40(5): 534-546.

PINTO LC, DE MELLO CR, NORTON LD, SILVA SHG, TAVEIRA LRS AND CURI N. 2017. Land-use effect on hydropedology in a mountainous region of Southeastern Brazil. Ciênc e Agrotec 41(4): 413-427.

RESENDE M, CURI N, REZENDE SB, CORRÊA GF AND KER JC. 2014. Pedologia: Base para distinção de ambientes. 6th ed., Lavras: Editora UFLA, 378 p.
RODRIGUES HJB, DE ABREU SÁ LD, RUIVO MLP, COSTA ACL, SILVA RB, MOURA QL DE AND DE MELLO IF. 2011. Variabilidade quantitativa de população microbiana associada às condições microclimáticas observadas em solo de floresta tropical úmida. Rev Bras Meteorol 26(4): 629-638.

RYZAK M, BARTMINSKI P AND BIEGANOWSKI A. 2009. Methods for determination of particle size distribution of mineral soils. Institute of Agrophysics, Acta Agrophys 175(4): 1-84.

SÁ JÚNIOR A AND DE CARVALHO LG. 2012. Application of the Köppen classification for climatic zoning in the state of Minas Gerais , Brazil. Theor Appl Climatol 108(1): 1-7.

SANTOS HG, JACOMINE PKT, ANJOS LHC, OLIVEIRA VA, LUMBRERAS JF, COELHO MR, ALMEIDA JA, ARAÚJO FILHO JC, OLIVEIRA JB AND CUNHA TJF. 2018. Sistema brasileiro de classificação de solos. ( $\left.5^{\text {a }}\right)$. Rio de Janeiro: Embrapa, 356 p.

SANTOS JV, VARÓN-LÓPEZ M, FONSÊCA SOUSA SOARES CR, LOPES LEAL P, SIQUEIRA JO AND DE SOUZA MOREIRA FM. 2016. Biological attributes of rehabilitated soils contaminated with heavy metals. Environ Sci and Pollut R 23(7): 6735-6748.

SHOEMAKER HE, MCLEAN EO AND PRATT PF. 1961. Buffer Methods for Determining Lime Requirement of Soils With Appreciable Amounts of Extractable Aluminum¹. Soil Sc Soc Am J 25(4): 274.

SILVA AO, COSTA AMA, TEIXEIRA AFS, GUIMARÃES AA, SANTOS JV AND MOREIRA FMS. 2018. Soil microbiological attributes indicate recovery of an iron mining area and of the biological quality of adjacent phytophysiognomies. Ecol Indic 93: 142-151.

SILVA IR DE, MELLO CMA DE, FERREIRA NETO RA, SILVA DKA DE, MELO AL DE, OEHL F AND MAIA LC. 2014. Diversity of arbuscular mycorrhizal fungi along an environmental gradient in the Brazilian semiarid. Appl Soil Ecol 84: 166-175.

SILVA SHG, MENEZES MD DE, OWENS PR AND CURI N. 2016a. Retrieving pedologist's mental model from existing soil map and comparing data mining tools for refining a larger area map under similar environmental conditions in Southeastern Brazil. Geoderma 267: 65-77.

SILVA SHG, POGGERE GC, MENEZES MD, CARVALHO GS, GUILHERME LRG AND CURI N. 2016b. Proximal sensing and digital terrain models applied to digital soil mapping and modeling of Brazilian Latosols (Oxisols). Remote Sens 8(8): 614

SOIL SURVEY STAFF. 2014. Keys to soil taxonomy. Soil Conservation Service 12: 410.

SORIANO S AND WALKER N. 1968. Isolation of ammoniaoxidizing autotrophic bacteria. The J Appl Bact 31(4): 493-497. 
ŠTURSOVÁ M, BÁRTA J, ŠANTRU゚ČKOVÁ H AND BALDRIAN P. 2016. Small-scale spatial heterogeneity of ecosystem properties, microbial community composition and microbial activities in a temperate mountain forest soil. FEMS Microbiol Ecol 92(12): 185.

SWIFT MJ, BIGNELL D, MOREIRA FMS AND HUISING J. 2010. O inventário da diversidade biológica do solo: conceitos e orientações gerais. In: Moreira FMS, Huising EJ and Bignell DE (Eds), Manual de Biologia dos Solos Tropicais: Amostragem e Caracterização da Biodiversidade. Lavras: Editora UFLA, p. 23-42.

SYLVESTER-BRADLEY R, ASAKAWA N, LA TORRACA S, MAGALHÃES FMM, OLIVEIRA L AND PEREIRA RM. 1982. Levantamento quantitativo de microrganismos solubilizadores de fosfatos na rizosfera de gramíneas e leguminosas forrageiras na Amazônia. Acta Amaz 12: 1522.

TABATABAI MA. 1994. Enzymes. In: Weaver RW, Augle S, Bottomly PJ, Bezdicek D, Smith S, Tabatabai A and Wollum A (Eds), Methods of Soil Analysis. Part 2. Microbiological and Biochemical Properties, No. 5. Madison: Soil Sci Soc Am, p. 775-833.

TABATABAI MA AND BREMNER JM. 1972. Assay of urease activity in soils. Soil Biol Biochemy 4(4): 479-487.

TAGHIZADEH-MEHRJARDI R, NABIOLLAHI K, MINASNY B AND TRIANTAFILIS J. 2015. Comparing data mining classifiers to predict spatial distribution of USDA-family soil groups in Baneh region, Iran. Geoderma 253-254: 67-77.

THORNTON HG. 1922. On the development of a standardised agar medium for counting soil bacteria, with especial regard to the repression of spreading colonies. Ann Appl Biol 9(3-4): 241-274.

WALKLEY A AND BLACK IA. 1934. An examination of the Degtjareff method for determining soil organic matter and a proposed modification of the chromic acid titration method. Soil Sci 37(1): 29-38.

WOLLUM AG. 1982. Cultural methods for soil microorganisms. In: Page AL, Miller RH and Keeney DR (Eds), Methods of Soil Analysis. Madison: Soil Sci Soc Am, p. 781-802. 